\title{
Leadership in working with communities and adaptation to the impacts of sea-level rise: interaction among federal agencies, NGO's, scientists, and community leaders
}

\author{
Norbert P. Psuty, Institute of Marine and Coastal Sciences, Rutgers University, psuty@marine.rutgers.edu \\ Tanya M. Silveira, Institute of Marine and Coastal Sciences, Rutgers University, mendes@marine.rutgers.edu \\ Andrea Spahn, Institute of Marine and Coastal Sciences, Rutgers University, spahn@marine.rutgers.edu \\ Barry Sullivan, Gateway National Recreation Area, National Park Service, barry_sullivan@nps.gov \\ David Avrin, Gateway National Recreation Area, National Park Service, dave_avrin@nps.gov \\ Hollis Provins, Gateway National Recreation Area, National Park Service, hollis_provins@nps.gov \\ Michael DeLuca, Institute of Marine and Coastal Sciences, Rutgers University, deluca@marine.rutgers.edu \\ Lisa Auermuller, Jacques Cousteau National Estuarine Research Reserve, auermull@marine.rutgers.edu
}

\begin{abstract}
The emerging concern regarding impacts of sea-level rise amongst the U.S. coastal national parks is the impetus for reaching beyond the jurisdictional limits of the parks to engage the adjacent communities in identifying natural and cultural resources at risk and adaptation strategies to address the concerns. In the first meeting of its kind in the Northeast, the Gateway National Recreation Area of the National Park Service and NOAA's Jacques Cousteau National Estuarine Research Reserve involved seven communities in a workshop on environmental changes affecting the Raritan Bay shoreline. The thrust was to describe the background science on sea-level rise in the immediate area, the dimensions and directions of ecological adjustments in the Park, the impacts to existing infrastructure, and the possible responses in a management context. Scientists from Rutgers University, personnel from the NOAA Coastal Services Center, the local county GIS office, and two NGOs provided assistance and information. The goal was to use the National Park as an example of an approach to understand the conditions that are occurring at the local scale and to identify resources available to the municipal residents and officials. It was an instance of leadership by example in a non-competitive setting.
\end{abstract}

Keywords: Sea-level rise, Adaptation, National Park Service, Coastal communities

\section{Introduction:}

Concern with the impacts of sea-level rise has driven action on many levels. The reports issued by the Intergovernmental Panel on Climatic Change (Bindoff, et al., 2007) has raised the specter of loss of natural resources and community infrastructure as global warming and associated sea-level rise alter the coastal environment. In partial response, a number of agencies in the United States have adopted plans to adapt to, to mitigate, or to defend against the impacts of an increased ocean level at the coast. For example, the state of Washington has created a SLR plan (Saavedra and Budd 2008) that is largely a recognition of the effects but does not have a prescription to deal with the matter on a site-specific basis. At the national level, the NOAA Coastal Services Center (CSC) is active in communicating concerns and strategies to cope with climate change (NOAA CSC, 2010). It has also developed a suite of decision-support tools that are freely available from the Internet to help 
coastal communities in dealing with their management issues (www.csc.noaa.gov). Whereas the CSC program proclaims to focus on sustainability, the self-evaluations tend to support defense of the status quo in the face of a changing environment. In many respects, the concepts of sustainability proffered by most agencies are biased toward creating barriers to the inundation and its associated impacts. Some of the national agencies are establishing the dimensions of the impending change (Hammar-Klose et al., 2001), whereas others are developing strategies to cope with the impending environmental changes and are seeking to create management programs that address both the changes and the adaptations to the changes. One of the agencies in the forefront of the latter direction is the National Park Service (NPS) of the US Department of the Interior. For the past several years, the NPS has been promoting its Climate Friendly Parks initiative that is directed toward a reduction of its carbon footprint within each park (including park personnel and visitors) (www.nps.gov/climatefriendlyparks/; NPS 2007). Moreover, several of the coastal parks have taken steps to address global climate change and sea-level rise in their management strategies. Specifically, Gateway National Recreation Area (coastal New York and New Jersey) (Fig. 1) is in the forefront of recognising impacts to its environmental system and is developing a new General Management Plan that has global climate change and sea-level rise as core elements of programs to manage its natural and cultural resources (Kirchhoff et al., 2009). Through a gathering of basic physical data of the environmental system, and with the input of scientists and technical support from partnering institutions (Gornitz et al., 2002; Psuty et al., 2010; Renfro et al., 2010), Gateway NRA is able to consider and evaluate a wealth of information associated with long-term changes and impacts. However, the Park is not functioning in spatial isolation and, consequently, it is very interested in the coastal conditions of the surrounding areas.

\section{Community Outreach by Example}

In June 2009, Gateway NRA and the Jacques Cousteau National Estuarine Research Reserve organised a workshop on the topic of coastal adaptation to sea-level rise. It was directed at seven communities that share the Raritan Bay shoreline with the Park (Fig. 1). The thrust of the workshop was to present and discuss general information assembled by the Park in its goal to understand and to adapt to the impact of sea-level rise, specifically along the bayside shoreline. In so doing, the Park took the lead on assembling the basic knowledge of the local system and the variety of techniques available to apply the knowledge to better manage the region's natural and cultural resources. With the focus on information generated either in the Park by others or through Park initiatives, members of the workshop were offered scientific evidence for the local rate of sea-level rise (Fig. 2), using data derived from a US National Ocean Service tidal gauge operating on Sandy Hook. 


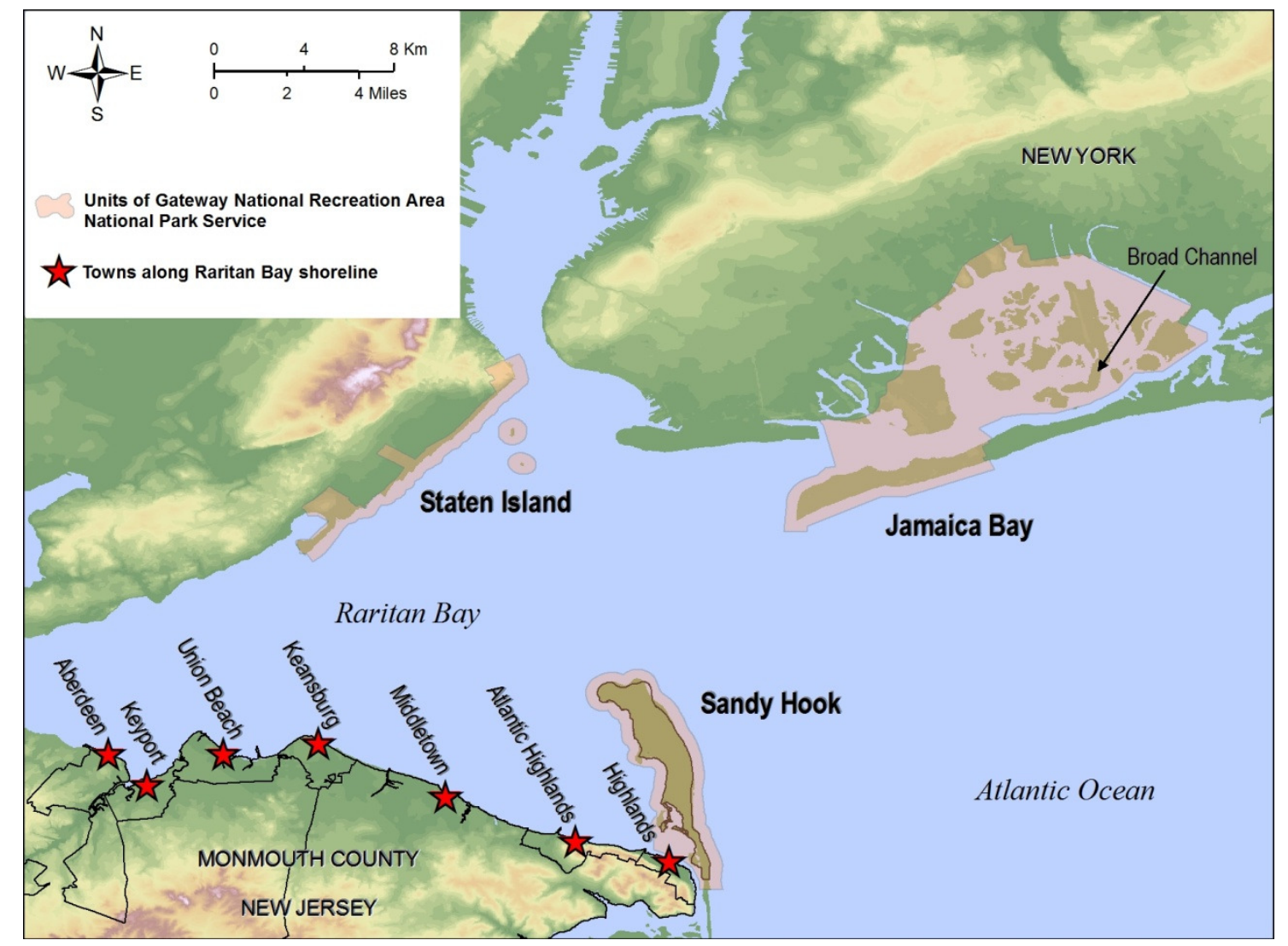

Fig. 1. Location of the units of Gateway NRA and the seven towns on Raritan Bay shoreline that were invited to the workshop. The Broad Channel location is the site for modeling the impacts of sea-level rise in a community.

The significance of the local dimension of existing sea-level rise was further expanded by describing the vectors of shoreline displacement under the influence of sea-level rise, the inundation of fixed structures under scenarios of future water-level conditions, and probable impacts of selected storm events. In particular, situations of change at the estuarine shoreline were modeled by representing mean high tide levels on topographical models derived from the latest LiDAR (Light Detection and Ranging) data sets. In one case, the

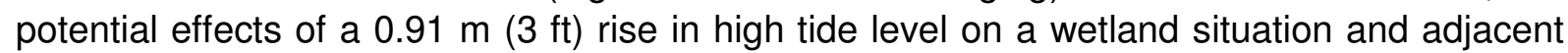
infrastructure were demonstrated (Fig. 3). In another case, the impacts to roads and fixed town development were modeled (Fig. 4).

The availability and application of LiDAR to the communities was demonstrated as being a valuable tool to generate improved topographical models that provide a better understanding of the topography, and help to identify the levels of expected inundation and the locations of inundation. 


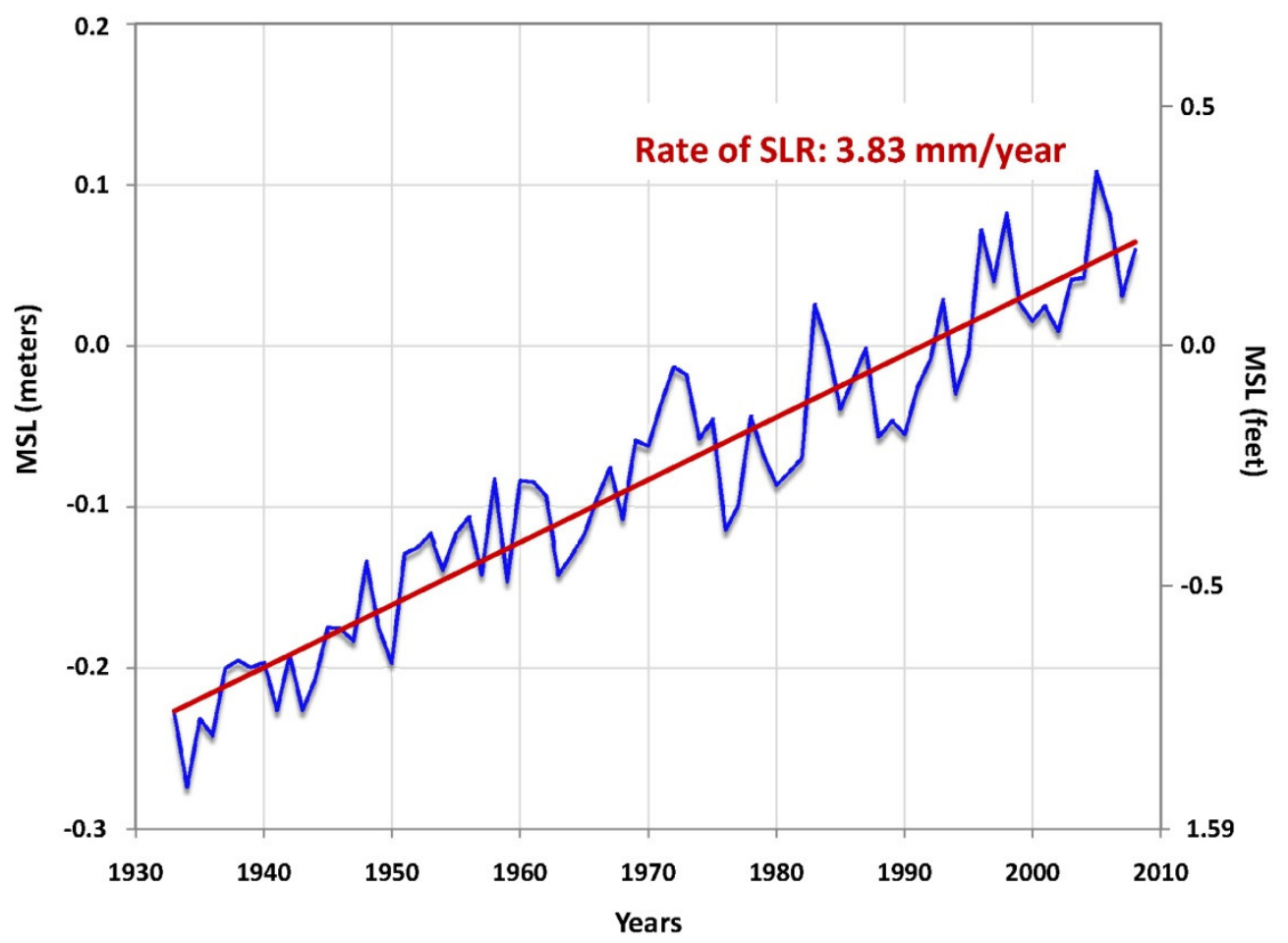

Fig. 2. Historical rate of sea-level rise derived from record of mean annual sea level at Sandy Hook, NJ, 1933-2008. Data available at: tidesandcurrents.noaa.gov

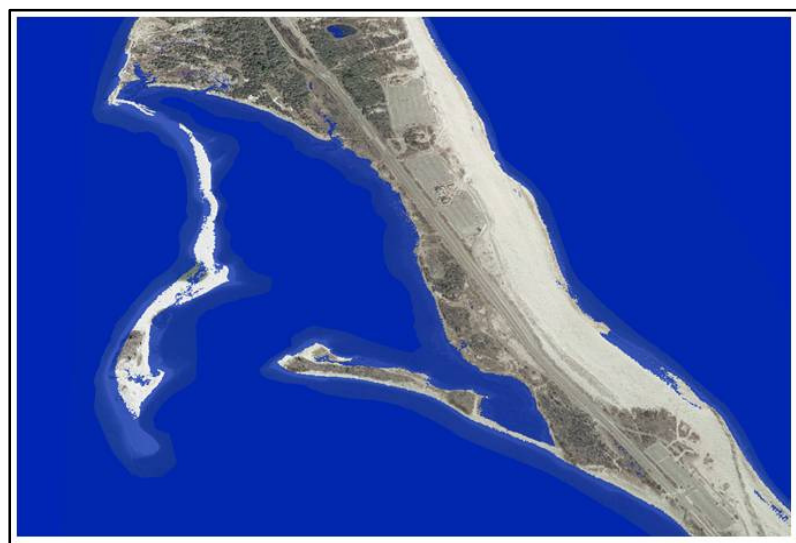

Actual Mean High Water

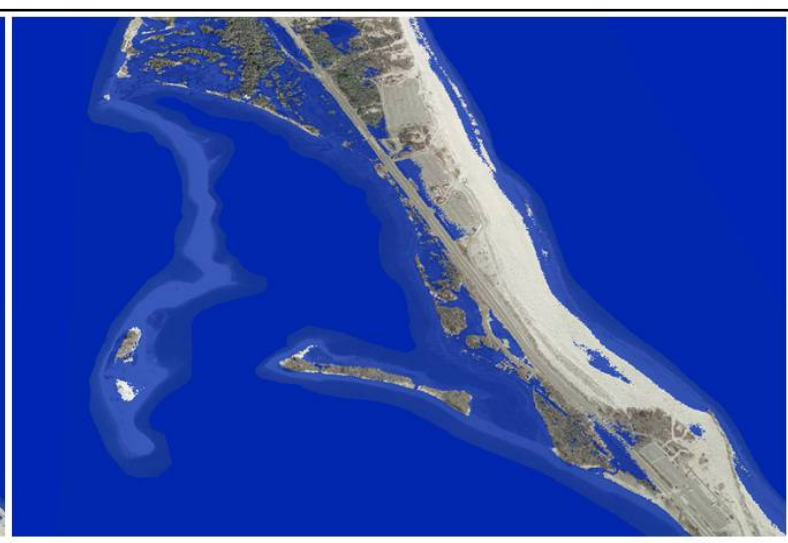

Predicted Mean High Water $-\mathbf{3} \mathrm{ft}$ Sea Level Rise

Fig. 3. Model of displacement of shoreline features and wetlands compared in locations of natural conditions and locations with hardened infrastructure, bayside of Sandy Hook Unit of Gateway NRA. In many locations, the natural ecological system was maintained by shifting inland. However, at sites with hard structures (roads, wall, parking lots), the ecological units were diminished or lost. 


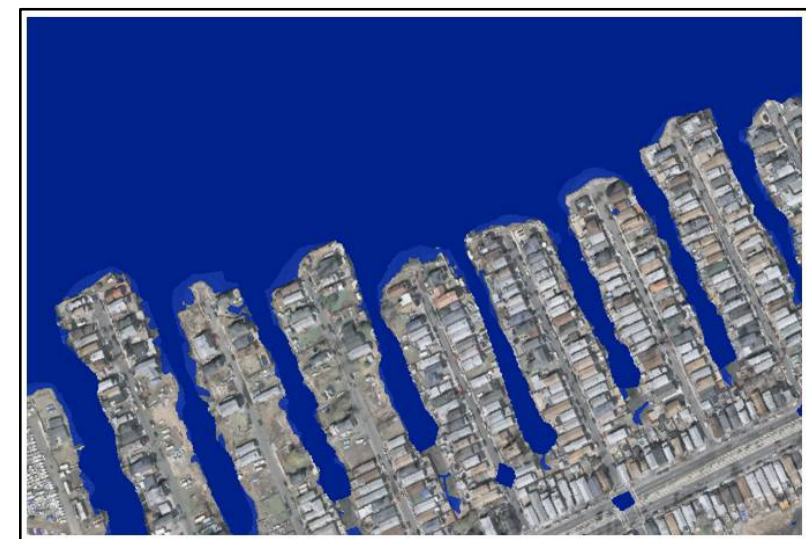

Actual Mean High Water

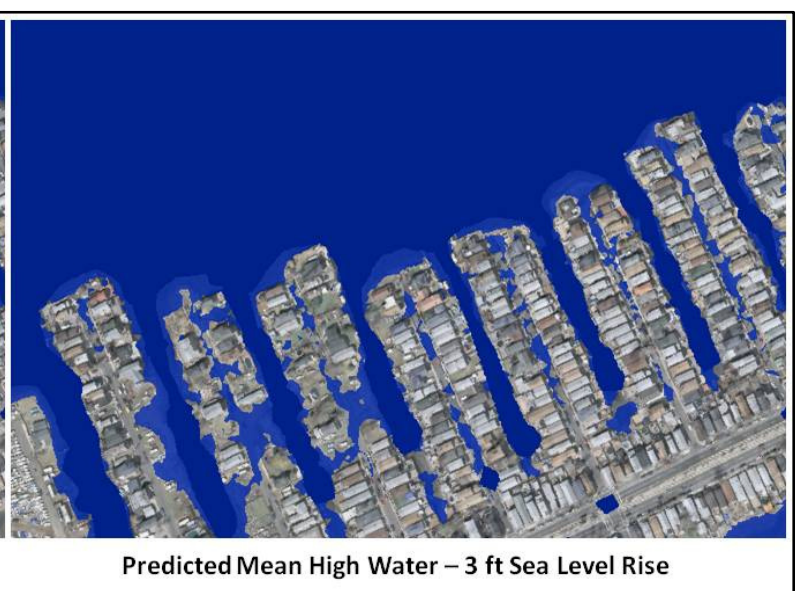

Predicted Mean High Water $-3 \mathrm{ft}$ Sea Level Rise

Fig. 4. Model of inundation in Broad Channel, a community situated within the Park, with impact to roads and buildings. Because this development is at a very low elevation, some portions of the community are isolated by the rising water.

\section{Knowledge as a Variable}

The workshop pointed to the generation of data sets that permitted the Park to begin to address SLR impacts because it had taken steps to conduct studies and to participate in experimental programs that returned appropriate information about the environment at risk. And, to further the communication to the local communities, the workshop involved the Monmouth County Planning Department and the Monmouth County Geographical Information System Office. This was very important because most of the small towns were staffed by part-time local officials and there was very little GIS capability at that level. Importantly, the County Planner communicated to the towns the concern about areas that were going to be affected by rising sea level and some of the options that are being discussed to address the situation. Further, the County GIS office identified the new information that was being generated and will be generated with LiDAR and the opportunities to share this information with the towns. Perhaps of greatest importance was the willingness of the County GIS Office to share the expertise in the use of the spatial data of value in both understanding the impacts and their spatial distribution.

\section{Web-based Resources}

Whereas the Park was communicating its experience in dealing with the global change conditions, another Federal program (NOAA's Coastal Services Center) and The Nature Conservancy (non-profit environmental group) introduced the workshop participants to a suite of web-based resources that could be of value in establishing a community response to aspects of change in a coastal setting. In particular, the Coastal Services Center provided information on the availability of a number of 'how to' guides and tools (www.csc.noaa.gov) that combine basic descriptions of planning tools as well as tutorials for applying the tools.

Using the CSC planning approach as its core, The Nature Conservancy (TNC) developed and applied its Coastal Resilience tool (www.coastalresilience.org/) to a portion of coastal Long Island to demonstrate the opportunity to factor sea-level rise in a planning matrix. The project is giving complete information to natural resource and land use managers, enabling them to move towards socioeconomic and ecological resilience. The data layers in this webbased GIS platform include wetlands, population density, economic value of property, and 
possible future impacts in 2020, 2050, and 2080. Three different flooding scenarios are used: the 5-year flood, Category II storm, and Category III storm. The recommendations for adaption were to amend key laws, realign public structures, promote voluntary land acquisition, plan for post-storm redevelopment, and restore key coastal habitats. Importantly, the device prepared by TNC provides a suite of interactive options that can provide analytical outcomes to choices exercised by community decision-makers.

\section{Outcomes}

A group discussion led by members of the American Littoral Society identified a variety of local concerns regarding apparent conflicts in agency policies that spur development into marginal and hazardous areas. Too often, the local governments are focusing on the present day problems and find it difficult to consider the long-range effects, especially those options that require present-day funding. Because the local communities have limited access to the latest technologies, there is a need to address these broad issues on a regional scale and provide advice to the local officials. There was a consensus amongst the participants that this type of workshop should be offered to a broader representation of town officials and members of the planning boards. A further workshop was recommended.

\section{Conclusions}

The goal of leadership by example succeeded in generating local interest in the knowledge of sea-level rise and its impacts on natural and cultural resources. The Park and other participating agencies demonstrated the wealth of existing information and tools to assist in local planning for impacts of aspects of sea-level rise. However, the issues of impacts associated with sea-level rise are regional and need to be addressed at that level, with advice and direction communicated to the towns.

\section{References}

Bindoff, N.L., J. Willebrand, V. Artale, A, Cazenave, J. Gregory, S. Gulev, K. Hanawa, C. Le Quéré, S. Levitus, Y. Nojiri, C.K. Shum, L.D. Talley and A. Unnikrishnan, 2007. Observations: Oceanic Climate Change and Sea Level. In: Climate Change 2007: The Physical Science Basis. Contribution of Working Group I to the Fourth Assessment Report of the Intergovernmental Panel on Climate Change [Solomon, S., D. Qin, M. Manning, Z. Chen, M. Marquis, K.B. Averyt, M. Tignor and H.L. Miller (eds.)]. Cambridge University Press, Cambridge, United Kingdom and New York, NY, USA.

Gornitz, F, S. Couch, and E.K. Hartig, 2002. Impacts of sea level rise in the New York City metropolitan area. Global and Planetary Change 2: 61-88.

National Park Service, 2007. Climate Change and Impact to Resources Around the Great Lakes. Climate Change Talking Points NPSNRSS -2007/001, 15 p.

Hammar-Klose, E.S., and E.R. Thieler, 2001. Coastal Vulnerability to Sea-Level Rise: A Preliminary Database for the U.S Atlantic, Pacific and Gulf of Mexico Coasts. U.S. Geological Survey Digital Data Series - 68. Woods Hole, MA, CD-ROM.

Kirchhoff, K., L. Stokes, A.B. Cuevas, L. Chan, M. Filipovic, G. Goodrich, J. Haller, K. Kasman, M. Miller, C. Orr, and T. Sinnickson, 2009. Gateway National Recreation Area: Longterm Resource Management Under a Changing Climate. Columbia University, School of International and Public Affairs, New York, NY, 74 p. 
NOAA Coastal Services Center, 2010. Local Strategies for Addressing Climate Change, Vol. 2. NOAA National Ocean Service, Charleston, SC, 39. p.

Psuty, N. P., P. Dennehy, T. Silveira, and N. Apostolou. 2010. Coastal geomorphology of the ocean shoreline, Gateway National Recreation Area: natural evolution and cultural modifications, a synthesis. Natural Resource Report NPS/NERO/NRR-2010/184. Fort Collins, Colorado, $41 \mathrm{p}$.

Renfro, A., J. K. Cochran, D. J. Hirschberg, and S. L. Goodbred. 2010. Natural radionuclides $\left({ }^{234} \mathrm{Th},{ }^{7} \mathrm{Be}\right.$ and $\left.{ }^{210} \mathrm{~Pb}\right)$ as indicators of sediment dynamics in Jamaica Bay, New York. Natural Resource Technical Report NPS/NERO/NRTR-2010/324. Fort Collins, Colorado, 96 p.

Saavedra, C., and W.W. Budd, 2008. Climate change and environmental planning: Working to build community resilience and adaptive capacity in Washington State, USA. Habitat International 33: 246-252.

Tang, Z., S.D. Brody, C. Quinn, L. Chang, and T. Wei, 2010. Moving from agenda to action: Evaluating local climate change action plans. Journal of Environmental Planning and Management 53: 41-62.

\section{Websites}

National Park Service: http://www.nps.gov/climatefriendlyparks/

The Nature Conservancy: http://www.coastalresilience.org/

NOAA Coastal Services Center: http://www.csc.noaa.gov/ 